\title{
MOTIVASI KERJA DALAM RANAH LOKALITAS TEKS SUCI*
}

\author{
Maman Rahman Hakim ${ }^{1}$ \\ Permalink: https://www.academia.edu/9997915
}

\begin{abstract}
Work Motivation in Local Sphere of Sacred Texts. Work motivation is one of important components in human life. Work motivation also benefits to determine planning, withdrawal of labor, selection process, development, work evaluation, compensation, safety, health and career development, relationship of companies with the employees, organizational restructuring and research on human resources. Those reasons become work motivation along with management as a policy maker which can be seen from factors of planning, directing, and supervising. These factors impact on work motivation to born and develop with basic competences which are compulsory for companies. Islam views work motivation as a requirement to worship.
\end{abstract}

Keywords: motivation, work, sacred texts

Abstrak: Motivasi Kerja Dalam Ranah Lokalitas Teks Suci. Motivasi kerja merupakan salah satu komponen penting dalam sumber daya manusia. Motivasi kerja juga berguna dalam menentukan perencanaan, penarikan tenaga kerja, seleksi, pengembangan, penilaian kerja, kompensasi, keselamatan dan kesehatan serta perencanaan karir, hubungan dalam perusahaan dengan anggotanya, restrukturisasi organisasi dan riset sumber daya manusia. Alasan tersebutlah memotivasi kerja sejalan dengan manajemen sebagai pembuat kebijakan yang secara garis besar dapat dilihat dari unsur manajemen perencanaan, pengorganisasian, pengarahan, pengawasan. Atas dasar ini, motivasi kerja lahir dan berkembang diiringi kompetensi dasar yang wajib dimiliki oleh setiap insan perusahan, baik level atas sampai bawah. Islam pun memandang motivasi kerja sebagai syarat dan rukun beribadah dengan tidak mengindahkan ketentuan yang mendasarinya.

Kata kunci: motivasi, kinerja, Teks Suci

Diterima tanggal naskah diterima: 14 Juni 2014, direvisi: 25 Oktober 2014, disetujui untuk terbit: 14 November 2014.

${ }^{1}$ Fakultas Syariah dan Hukum UIN Jakarta. Jl. Ir. H Juanda No 95. Ciputat. E-mail: maman.rahmanhakim@gmail.com 


\section{Pendahuluan}

Manusia sebagai insan menjadi fokus perhatian utama dalam peningkatan kualitas sumber daya manusia karena menjadi dasar dari kehidupan dirinya. keberhasilan dalam membangun manusia sebagai insan seutuhnya akan menentukan keberhasilan membangun manusia pada sisi lainnya, yakni pelaku yang tangguh dalam membangun diri dan lingkungannya dengan berbekal pengetahuan, keterampilan, dan akhlak yang baik.

Pembangunan manusia sebagai insan tidak terbatas pada kelompok dan umur tertentu, tetapi berlangsung dalam seluruh kehidupan manusia sejak janin sampai usia lanjut. Setiap tahap dari pertumbuhan tersebut, terutama tahap awal, sangat mempengaruhi kualitasnya sehingga perhatian yang sungguhsungguh akan membentuk manusia yang tangguh, baik dalam sikap mental, daya pikir maupun daya ciptanya, serta sehat jasmani dan rohaninya.

Pembangunan manusia sebagai sumber daya pembangunan menekankan manusia sebagai pelaku pembangunan yang memiliki etos kerja produktif, keterampilan, kreatifitas, disiplin, profesionalisme, serta memiliki kemampuan memanfaatkan, mengembangkan, dan menguasai ilmu pengetahuan dan teknologi serta kemampuan manajemen. Kualitas manusia sebagai insan dan sumber daya pembangunan seperti itu akan membawa Indonesia tumbuh dan maju menjadi bangsa besar yang sejajar dengan bangsa lainnya.

Sebuah motivasi kerja baik untuk diri sendiri maupun organisasi memerlukan sejumlah tenaga kerja dalam usaha mewujudkan eksistensinya, yang terarah pada pencapaian tujuannya berupa keuntungan dalam berbisnis. Tenaga kerja tersebut berfungsi sebagai pelaksana pekerjaan yang menjadi tugas pokok organisasi/perusahaan. Oleh karena itulah rekrutmen sebagai salah satu kegiatan manajamen sumber daya manusia tidak dapat dilepaskan kaitannya dengan kegiatan lainnya. Dengan kata lain proses rekrutmen tidak dapat dilepaskan kaitannya dengan deskripsi dan atau spesifikasi pekerjaan atau jabatan sebagai hasil analisis pekerjaan/jabatan yang memberikan gambaran tentang tugas-tugas pokok yang harus dikerjakan.

Pada titik inilah motivasi dan kinerja dalam proses rekrutmen tidak pula dilepaskan kaitannya dengan perencanaan sumber daya manusia sebagai kegiatan manajemen. Dari perencanaan sumber daya manusia dapat diketahui pekerjaan yang diperlukan, baik secara kuantitatif maupun kualitatif. Selanjutnya ketepatan melakukan kegiatan rekrutmen, akan terlihat dari hasil penilaian karya setelah para pekerja melaksanakan tugas pokok-pokoknya untuk suatu periode tertentu.

Pekerjaan sudah lumrah dan seyogyanya memiliki tingkatan kinerja berbeda-beda dan juga berubah-ubah. Ada pekerja yang selalu terlihat semangat bekerja karena menginginkan kenaikan gaji atau promosi jabatan atau hanya sebatas ke ikhlasan saja, hal tersebut tentunya wajar-wajar saja. Motivasi kerja pun bisa naik-turun, tidak selamanya kegairahan/supporting dalam bekerja bisa terus berada pada titik maksimal. Kadang kala, seseorang pekerja dapat mengalami penurunan kinerja karena kejenuhan dalam bekerja, atau bisa saja 
karena berbagai permasalahan yang dihadapinya. Motivasi adalah hal yang dapat membuat kegairahan dalam bekerja. Titik fokus artikel ini adalah bagaimana Islam memandang dua kutub motivasi seseorang dalam bekerja dengan beragam dinamika yang terjadi serta merujuk pada ayat-ayat tentang motivasi itu sendiri. Motivasi kerja dalam Islam diartikan untuk mencari nafkah yang merupakan bagian dari ibadah. Entry pointnya yakni motivasi kerja dalam sudut pandangan Islam bukanlah untuk mengejar kehidupan yang hedonis, bukan juga untuk status, apalagi untuk mengejar kekayaan dengan segala cara, tetapi untuk beribadah. Bekerja untuk mencari nafkah adalah hal yang istimewa dalam pandangan Islam.

\section{Konseptualisasi Motivasi kinerja}

Term penyebutan istilah motivasi (motivation) berasal dari perkataan bahasa latin, yakni movere, yang berarti "menggerakkan. ${ }^{2}$ Dalam Kamus Besar Bahasa Indonesia dikemukakan bahwa pengertian motivasi didefinisikan antara lain yaitu (1) Dorongan yang timbul pada diri seseorang secara sadar atau tidak sadar untuk melakukan suatu tindakan dengan tujuan tertentu. (2) Usaha yang menyebabkan seseorang atau kelompok orang tertentu tergerak melakukan sesuatu karena ingin mencapai tujuan yang dikehendakinya atau mendapat kepuasan dengan perbuatahnnya ${ }^{3}$ lain hal nya dengan kinerja pengertian kinerja adalah: (1) sesuatu yang dicapai; (2) prestasi yang diperlihatkan, dan (3) kemampuan kerja (tentang peralatan). ${ }^{4}$

Bertitik tolak dari pengertian etimologis di atas, AA Anwar Prabu Mangkunegara prinsip motivasi kerja pegawai yaitu prinsip partisipasi, komunikasi, prinsip mengakui adil bawahan, prinsip pendelegasian wewenang dan yang terakhir yaitu prinsip perhatian. ${ }^{5}$

Lebih lanjut, Menurut AA.Anwar Prabu Mangkunegara dalam bukunya mengemukakan bahwa teori motivasi terbagai setidaknya terbagi 3 teori antara lain;

Pertama, Teori kebutuhan. ${ }^{6}$ Kebutuhan didefinisikan sebagai suatu kesenjangan atau pertentangan yang dialami antara suatu kenyataan dengan dorongan yang ada dalam diri. Senada dengan itu Abraham Maslow mengemukanan hirarki kebutuhan manusia meliputi; Pertama, kebutuhan psikologis yaitu kebutuhan untuk makan, minum, perlindungan fisik, bernafas, seksual. Kedua, kebutuhan rasa aman yaitu kebutuhan akan perlindungan dari ancaman bahaya, pertentangan dan lingkungan hidup. Ketiga, kebutuhan

${ }^{2}$ Lihat Sondang P. Siagian, Teori Motivasi dan Aplikasinya (Jakarta: PT.Rineka Cipta, 1995) h. 138

${ }^{3}$ Kamus Besar Bahasa Indonesia, (Jakarta, PT Gramedia Pustaka Utama,2008) h. 503

${ }^{4}$ Kamus Besar Bahasa Indonesia, (Jakarta, PT Gramedia Pustaka Utama,2008) h.503

5 AA Anwar Prabu mangkunegara, Manajemen Sumber Daya Manusia Perusahaan (Bandung : PT. Remaja Rosdakarya, 2007) hlm 101

${ }^{6}$ Teori motivasi yang paling terkenal adalah hierarki kebutuhan (hierarchy of needs) milik Abraham Moslow lihat A. Moslow, Motivation and personality, (New York: Harper \& Row, 1954) 
untuk merasa memiliki yaitu kebutuhan untuk diterima oleh kelompok, berafiliasi, berinteraksi, dan kebutuhan untuk mencintai dan dicintai. Keempat, kebutuhan akan harga diri, yaitu kebutujan untuk dihormati dan dihargai oleh orang lain. Kelima, Kebutuhan untuk mengaktualisasikan diri, yaitu kebutuhan untuk menggunakan kemampuan, skill dan potensi. ${ }^{7}$

Kedua, Teori ERG (exsistence, relatedness, growth) teori ini berasal dari alderfer yang merupakan refleksi tiga dasar kebutuhan, yaitu: Pertama, existence needs.kebutuhan ini berhubungan dengan fisik dari eksistensi pegawai, seperti makan, minum, pakaian, bernapas, gaji, keamanan dan kondisi kerja, finger benefits. Kedua, relatednes needs. Kebutuhan interpersonal, yaitu kepuasan dalam berinteraksi dalam lingkungan kerja. Ketiga. Growth needs kebutuhan untuk mengembangkan dan meningkatkan pribadi.

Ketiga, Teori X-Y yang digagas oleh Dauglas Mc Gregor mengemukakan dua pandangan nyata mengenai manusia: pandangan pertama pada dasarnya negatif, disebut Teori $X$ (Theory $X$ ) dan yang kedua pada dasarnya positif, disebut Teori Y (Theory Y). ${ }^{9}$ Menurut asumsi teori $\mathrm{X}$ bahwa orang-orang ini pada hakikatnya adalah: 1). Tidak menyukai bekerja, 2). Tidak meyukai kemauan dan ambisi untuk bertanggung jawab dan lebih menyukai diarahkan, 3). Mempunyai kemampuan yang kecil untuk berkreasi mengatasi masalahmasalah organisasi. Hanya membutuhkan motivasi fisiologis dan keamanan saja, Harus diawasi secara ketat dan sering dipaksa untuk mencapai tujuan organisasi. ${ }^{10}$ Sedangkan asumsi Teori $\mathrm{Y}$ mengenai manusia adalah: 1). Karyawan menganggap kerja sebagai hal yang menyenangkan, seperti halnya istirahat dan bermain, 2). Karyawan akan berlatih mengendalikan diri dan emosi untuk mencapai berbagai tujuan, 3). Karyawan belajar untuk menerima, bahkan mencari, tanggung jawab, 4). Karyawan mampu membuat berbagai keputusan inovatif yang diedarkan keseluruh populasi dan bukan hanya bagi mereka yang menduduki posisi manajemen ${ }^{11}$

Dengan demikian hubungan motivasi kerja yakni didefinisikan sebagai kondisi yang berpengaruh membangkitkan, mengarahkan dan memelihara prilaku yang berhubungan dengan lingkungan kerja.

Dalam kontektualisasi teori motivasi kerja dalam islam yang erat kaitannya dengan tingkah laku bekerja sekiranya penting untuk dibicarakan dalam rangka mengetahui apa sebenarnya latar belakang suatu tingkah laku yang dikerjakan seseorang. Disinilah peranan motivasi itu sangat besar artinya dalam bimbingan dan mengarahkan seseorang terhadap tingkah laku yang sifatnya ajaran keagamaan. Namun demikian, adanya motivasi tertentu yang sebenarnya timbul dalam diri manusia karena terbukanya hati manusia

\footnotetext{
${ }^{7}$ AA Anwar Prabu mangkunegara, Manajemen Sumber Daya,,, h. 101

${ }^{8}$ AA Anwar Prabu mangkunegara, Manajemen Sumber Daya,,,, h. 98

${ }^{9}$ D.McGregor, The Human Side of Enterprice (New york: McGraw-Hill,1960)

${ }^{10}$ Miftah Thoha, Perilaku Organisasi Konsep Dasar dan Aplikasinya (Jakarta: PT Raja Grafindo Persada, 2008), h. 241-242

${ }^{11}$ Stephen P. Robbins, Timothy A. Judge,Perilaku Organisasi., h. 226
} 
terhadap hidayah Allah. Sehingga orang tersebut menjadi orang yang beriman dan kemudian dengan iman itulah ia lahirkan tingkah laku keagamaan yang sesuai dan dinamis. Penulis berpendapat teori motivasi kerja itu bagian impilikasi dari penerapan "niat" baik yang tersirat maupun tersurat dalam lubuk hati seseorang untuk mencapai tujuannya dalam hal apapun disertai dengan upaya yang komprehensif.

\section{Justifikasi Teks Suci dalam Motivasi Kerja}

Manusia diciptakan oleh Allah sebagai penerima dan pelaksana ajaran sehingga ia ditempatkan pada kedudukan yang mulia. Untuk mempertahankan kedudukannya yang mulia dan bentuk pribadi yang bagus itu, Allah melengkapinya dengan akal dan perasaan yang memungkinkannya menerima dan mengembangkan ilmu pengetahuan dan membudayakan ilmu yang dimilikinya. Ini berarti bahwa kedudukan manusia sebagai makhluk yang mulia itu karena akal dan perasaan, ilmu pengetahuan dan kebudayaan yang seluruhnya dikaitkan pada pengabdian untuk pencipta. ${ }^{12}$ Islam adalah agama yang oleh umatnya diyakini mengandung seperangkat nilai dasar untuk menuntun kehidupan manusia guna mencapai kebahagiaan baik di dunia maupun di akhirat.

Sebagai ajaran agama yang utuh dan lengkap, Islam tidak sekedar memberi atensi terhadap satu dimensi kehidupan, katakanlah jasmani semata tapi juga menekankan aspek rohani. Keduanya harus berada pada suatu keseimbangan. Setidaknya menurut Didin Hafidhuddin mengatakan seorang muslim dalam hidupnya terutama dalam bekerja harus mempunyai etos kerja muslim, yaitu: profesional, tekun, jujur, amah dan kreatif. ${ }^{13}$ Senafas dengan itu, hemat Amin Suma dalam berkerja setidaknya harus mempunyai filosofi kerja disingkat dengan BATARA yakni Bersih itu indah, Aman itu nyaman, Tertib itu lancar, Amanah itu tanggung jawab, Ramah itu ukhuwwah, Akhlaq itu terpuji. Selain itu juga dalam berkerja harus mempunyai tiga poros asas kerja yaitu:

Pertama, Profesional, maksudnya adalah bahwa dalam melakukan semua tugas dan wewenang yang menjadi tanggung jawab/unit kerja didasarkan pada tenaga lulusan pendidikan tinggi dan/atau lainnya yang memiliki keahlian dan keterampilan khusus dalam bidangnya; serta mendapatkan imbalan dan terutama penghasilan yang mensejahterakan para profesionalnya sesuai dengan peraturan dan perundang-undangan yang berlaku.

Kedua, Proporsional ialah bahwa semua dan setiap kebijakan dan pekerjaan pada dasarnya harus dilakukan sesuai atau sebanding dengan hal-hal yang terkait dengan pelaksanaan kebijakan dan atau tugas itu sendiri.

\footnotetext{
${ }^{12}$ Zakia Daradjat, Ilmu Pendidikan Islam, (Jakarta: Bumi Aksara, 1996), Cet. III, h.3

${ }^{13}$ Didin Hafidhuddin, Sifat Etos Kerja Muslim, artikel diakses 15 Oktober 2014 dari http://persis.or.id/site/modules.php?name=News\&file=article=84,
} 
Ketiga, prosedural, maksudnya dilakukan secara bertahap (tahap demi tahap)sesuai dengan tata kerja dan mekanisme serta prosedur yang harus dilalui sebagaimana diatur oleh lembaga. ${ }^{14}$

Ada yang menarik dikatakan oleh Ummu Yasmin bahwasannya ia mengatakan bahwa manusia pada konteks keislaman terdiri dari tiga unsur saling berkaitan, yaitu hati, Akal dan jasad. ${ }^{15}$ Atau yang sekarang lebih dikenal dalam istilah Emosional Quotient (EQ) untuk kecerdasan emosional, Spiritual Qoutient (SQ) untuk kecerdasan spiritual atau jiwa dan Intelectual Quotient (IQ) kecerdasan intelektual yang merujuk ke fungsi akal manusia. Hemat penulis di dalam Alquran juga setidaknya ada beberapa ayat yang berkaitan pada memotivasi setiap muslim untuk bekerja, seperti yang tergambar dalam firman-Nya:

Pertama, Dan Katakanlah: "Bekerjalah kamu, Maka Allah dan RasulNya serta orang-orang mukmin akan melihat pekerjaanmu itu, dan kamu akan dikembalikan kepada (Allah) yang mengetahui akan yang ghaib dan yang nyata, lalu diberitakan-Nya kepada kamu apa yang telah kamu kerjakan". (QS. atTaubah:105). Kedua, Apabila telah ditunaikan shalat, maka bertebaranlah kamu di muka bumi; dan carilah karunia Allah dan ingatlah Allah banyakbanyak supaya kamu beruntung. (QS. al-Jumu'ah: 10). Ketiga, Dan sesungguhnya kamu akan ditanya tentang apa yang telah kamu kerjakan.(QS. An-Nahl: 93). Kempat, Karena sesungguhnya orang yang paling baik yang kamu ambil bekerja (pada kita) ialah orang yang kuat lagi dapat dipercaya" (QS al-Qahshash:26) Kelima, Dan dia memperkenalkan (do'a) orang -orang beriman serta mengerjakan amal saleh dan menambah (pahala) kepada mereka dari karunianya” (QS. As-Syura 42:26). Keenam, "dan sesungguhnya kamu akan ditanya tentang apa yang telah kamu kerjakan.” (QS. An-Nahl 16 :93). Ketujuh, Hai orang-orang yang beriman, beriman, bertakwalah kepada Allah dan hendaklah setiap diri memperhatikan apa yang telah diperbuat untuk hari esok" (QS. Al-Hasyr: 18). Kedelapan, Berkatalah dia (Syu'aib): "Sesungguhnya Aku bermaksud menikahkan kamu dengan salah seorang dari kedua anakku ini, atas dasar bahwa kamu bekerja denganku delapan tahun dan jika kamu cukupkan sepuluh tahun Maka itu adalah (suatu kebaikan) dari kamu, Maka Aku tidak hendak memberati kamu. dan kamu insya Allah akan mendapatiku termasuk orang-orang yang baik". (QS. al-Qashash: 28: 27), Kesembilan, Katakanlah: "Sesungguhnya Tuhanku melapangkan rezki bagi siapa yang dikehendaki-Nya di antara hamba-hamba-Nya dan menyempitkan bagi (siapa yang dikehendaki-Nya)". Dan barang apa saja yang kamu nafkahkan, maka Allah akan menggantinya dan Dia-lah Pemberi rezki yang sebaik-baiknya. QS. Saba $(34: 39)$.

\footnotetext{
${ }^{14}$ Amin Suma, FSH UIN Syarif hidayatullah Jakarta; potret, keadaan dan Prospeknya, ( Jakarta, FSH Press, 2013) h.198

${ }^{15}$ Ummu Yasmin, Materi Tarbiyah: Panduan Kurikulum bagi Da’i dan Murabbi, (Solo: Media Insani Press, 2005) Cet. Ke-8, h. 109
} 
Beberapa ayat diatas mengindentifikasikan dan mengemukakan bahwa motivasi merupakan sebagai cara bekerja dalam melaksanakan tugas ("the way we do things around here") dan sebagai program kolektif kemampuan mental ("collective programming of the mind") sehingga konsep utama adalah adanya penghayatan bersama berkaitan dengan nilai, sasaran dan norma sebagai perekat, pelatihan dan pengembangan. Adapun pelatihan dan pengembangan sangat penting, karena keduanya merupakan cara yang digunakan organisasi untuk mempertahankan, menjaga, memelihara pegawai publik dalam organisasi dan sekaligus meningkatkan keahlian para pegawai untuk kemudian dapat meningkatkan produktivitasnya. ${ }^{16}$

Hal ini berarti jika manusia ingin maju dan sukses maka harus mau bekerja untuk mencukupi kebutuhan hidupnya. Allah Swt tidak akan memberikan rejeki secara cuma-cuma, Allah tidak akan memberi kesuksesan tanpa usaha. Kemudian pada kalimat selanjutnya disebutkan bahwa manusia tidak memiliki pelindung terhadap keburukan yang dikehendaki Allah, artinya bahwa manusia tidak bisa menghindar dari keburukan yang telah ditakdirkan oleh Allah untuk terjadi dalam hidup manusia. Tapi manusia berhak untuk menjaga kesehatan dan keselamatan dirinya dari ancaman yang terjadi dalam pekerjaannya dan motivasinya, manusia harus tetap berusaha untuk menyelamatkan diri dari berbagai bahaya yang mengintai di lingkungan sekitarnya. Masalah selamat atau tidak, hal itulah yang kemudian menjadi kuasa Allah untuk menentukan garis hidup manusia dalam kapasitas dan motivasinya serta kualitas pekerjaannya. Karena kulaitas pekerjaan tidak hanya menjadi sumber hukum semata, tetapi lebih dari itu sebagai landasan dan sumber nilai, serta moral sosial Islam, sehingga keadilan, kebebasan, kesetaraan, dan persamaan menjadi nilai universal dalam bingkai kesyariahan atau kemuamalatan demi menggapai maqâshid al-syarî̉ah.

Menjadi hal yang menarik ketika ingin mengungkap tujuan maqâshid alsyarîah (tujuan syariat) tersebut bermuara kepada lima kemaslahatan pokok manusia; yaitu agar terpelihara agama, jiwa, akal, keturunan/ kehormatan, dan harta $^{17}$ yang merupakan penjabaran atas hak-hak asasi manusia. Yang berarti di dalam syariat Islam dituntut terlaksananya kewajiban asasi manusia, baik bagi diri sendiri maupun kepada orang lain, agar tercapai atau terwujud hak-hak asasinya. Terlepas dari beberapa kriteria di atas, al-Thûfi mengatakan, bahwa kemaslahatan hukum atau kehidupan duniawi manusia diketahui olehnya melalui cara-cara alami yang diberikan Tuhan kepadanya, yakni sifat alami dari pengalaman-pengalaman hidup manusia sendiri dan dengan tuntutan akal atau

16 Ambar Teguh Sulistiyani dan Rosidah, Manajemen Sumber Daya Manusia, (Yogyakarta: Graha Ilmu, 2003) h. 175.

${ }^{17}$ Ali Hasballah, Ushûl al-Tasyrî̉ al-Islâmi, (Bairut: Dâr al-Fikr al-Arabi, 1982), h. 334 tentang konsep maslahah lihat pendapat syatibi menyatakan maslahah terdiri atas lima tujuan/prinsip dasar mencakup (1) memelihara agama (hifdh al-dîn), (2) memelihara jiwa ( al-nafs), (3) memelihara akal pikiran (hifdh al-'aql), (4) memelihara keturunan (hifdh al-nas), dan (5) memelihara harta kekayaan (hifdh al-mâl). Abû Ishâq al-Syâtibi, al-Muwâfaqât fi Ushûl al-Syarî‘ ah, (Beirut: Dar al-Kutub al-'Ilmiyyah, t.th.), Jilid I, Juz ke-2, h. 3-313 
intelegensianya sendiri. Cara alami ini, tegasnya, merupakan metode pemahaman dan pencapaian tujuan yang paling meyakinkan manusia. ${ }^{18}$ Sejalan dengan itu, Ibn Âsyûr mengklasifikasikan maqâshid al-syarî'ah dari segi objeknya menjadi tiga,yakni ${ }^{19}$ (1) maqâshid al-'âmmah (tujuan-tujuan umum), (2) maqâshid al-khâshshah (tujuan-tujuan khusus), (3) maqâshid al-juz'iyyah.

Kualitas pekerjaan merupakan bagian substansi yang tidak dapat diabaikan. Konsentrasi dari penilaian yang dilakukan tentunya akan mengidentifikasi bagaimana pencapaian kualitas pekerjaan yang di lakukan. tentu saja untuk menentukan kualitas tersebut sampai seberapa baik pencapaiannya, dengan cara membandingkan kualitas yang dicapai dengan target kualitas. Selanjutnya pengetahuan tentang pekerjaan juga menjadi fokus dalam penilaian. Banyaknya pegawai yang menguasai, memahami pekerjaan cenderung memberi dukungan untuk pencapaian kinerja yang tinggi. Di samping itu kreativitas juga memberikan inspirasi pencapaian kinerja. Ada tidaknya pedoman yang dapat digunakan dalam sebuah penilaian, sangat menentukan validitas hasil penilaian. Sebuah penilaian kinerja membutuhkan pedoman yang jelas, agar arah dari penilaian dapat lebih jelas dan lebih terukur. dalam memberikan penilaian, seorang penilai atau pemimpin hendaknya berpedoman pada ketentuan-ketentuan yang bersifat objektif, Adil, Konsekuen dan Mengikuti langkah-langkah yang telah di tentukan serta pengwasan yang mumpuni.

Pengawasan merupakan fungsi yang menjamin bahwa kegiatan-kegiatan dapat memberikan hasil seperti yang diinginkan. Semua sistem pengawasan melakukan pengumpulan, penyimpanan, dan pemindahan informasi tentang laba, penjualan, atau beberapa faktor lain. Dan semua sistem pengawasan dicapai dengan mempengaruhi perilaku. Pengawasan juga memerlukan ditetapkannya sasaran, standar, atau tujuan tertentu. Makanya perencanaan selalu dipakai bersam-sama dengan kata pengawasan. ${ }^{20}$ Dan, tentu dalam memaksimalkan dan mempertimbangkan pengawasan perlu di perhatikan perubahan stukutur dasar yang tidak perlu melampaui penilaian kita bisa mementukan situasi baiknya. Motivasi kerja dalam Islam itu adalah untuk mencari nafkah yang merupakan bagian dari ibadah tetapi tidak untuk mengejar hidup hedonis, bukan juga untuk status, apa lagi untuk mengejar kekayaan dengan segala cara. Dus, motivasi kerja dalam Islam, bukan hanya memenuhi nafkah semata tetapi sebagai kewajiban beribadah kepada Allah setelah ibadah fardlu lainnya. Bekerja untuk mencari nafkah adalah hal yang istimewa dalam pandangan Islam. Bahkan, lebih jauh, agama Islam memandang seseorang yang motivasi kerjanya untuk ibadah divonis/dipersamakan sebagai mujahid di jalan Allah dengan saratnya yakni berkarya dan terampil adapun ketentuan/aturan mainnya adalah kerja keras

18 'Abdallah M. Al-Husayn Al-'Amiri, Dekonstruksi Sumber Hukum Islam: Pemikiran Hukum Najm ad-Din Thufi, terj. Abdul Basir, (Jakarta: Gaya Media Pratama) h. 42

${ }^{19}$ Ibn 'Âsyûr, Maqâshid al-Syarî'ah al-Islâmiyyah, (Mesir: Dâr al-Salâm, 2005) h. 7

${ }^{20}$ Basu Swastha, Azas-Azas Manajemen Modern (Yogyakarta: Liberty. 2000), h. 216 
dengan semaksial dan optimal. ${ }^{21}$ Dengan demikian motivasi kerja merupakan suatu hal yang harus dijalankan sebagai mana mestinya untuk mengapai tujuan sa'adatud darain (kebahagian dunia dan ukhrawi).

\section{Penutup}

Berdasarkan beberapa pembahasan diatas, maka dapat disimpulkan bahwa motivasi kinerja pada dasarnya dapat dilihat dari tiga dimensi yang berbeda yaitu:(1)Sebagai keluaran (output), yakni dengan melihat apa yang telah dihasilkan oleh seseorang. Pada dimensi ini, kinerja seseorang lebih ditekankan pada hasil kerja yang dicapaikanya dalam kurun waktu tertentu. Hasil penelitian ini kemudian dibandingkan dengan tugas dan tanggung jawabnya yang telah ditentukan dalam uraian tugasnya (job description). (2)Sebagai aspek proses. Pada dimensi ini kinerja seseorang dinilai dari prosedur-prosedur yang telah ditempuh seseorang atau sekelompok orang dalam melaksanakan tugasnya. Bila dalam proses kerja pencapaian target dapat dilakukan sesuai dengan aturan yang berlaku, maka kinerja seseorang atau kelompok orang tersebut dikatakan baik. Namun apabila dalam proses pencapaian target terdapat pelanggaran hukum, maka kinerjannya harus dinyatakan tidak baik. (3) Sebagai aspek konstekstual, yakni penilai kinerja seseorang yang dilihat dari kemampuanya. Hal ini diasumsikan bahwa jika seseorang mampu mengerjakan pekerjaannya, maka kinerjanya juga akan baik. Dengan kata lain, apabila seseorang yang mempunyai pengalaman, pendidikan dan ketrampilan, serta ditempatkan pada posisi yang tepat, maka secara konseptual hal ini sudah benar dan diyakini kinerjanya akan baik. (4)Faktor penting dalam keberhasilan motivasi kinerja adalah adanya pegawai yang mampu dan terampil serta mempunyai semangat kerja yang tinggi, sehingga diharapkan suatu hasil kerja yang memuaskan. Pada kenyataannya tidak semua pegawai mempunyai kemampuan dan keterampilan serta semangat kerja sesuai dengan harapan, kadang-kadang tidak memiliki semangat tinggi sehingga kinerjanya tidak sesuai dengan yang diharapkan. Hal ini disebabkan biasanya terdiri atas individu-individu yang mempunyai latar belakang kehidupan berbeda satu sama lainnya, sehingga kadang-kadang berbeda dengan tujuan.

${ }^{21}$ Lihat hadis yang diriwayatkan Ahmad yang artinya "Sesungguhnya Allah suka kepada hamba yang berkarya dan terampil (professional atau ahli). Barangsiapa bersusah-payah mencari nafkah untuk keluarganya maka dia serupa dengan seorang mujahid di jalan Allah Azza wajalla. (Hr. Ahmad). Lihat juga, Barangsiapa pada malam hari merasakan kelelahan dari upaya keterampilan kedua tangannya pada siang hari maka pada malam itu ia diampuni oleh Allah. ( $\mathrm{Hr}$. Ahmad), lihat juga "Mencari rezeki yang halal adalah wajib sesudah menunaikan yang fardhu (seperti shalat, puasa, dIl). (Hr. Ath-Thabrani dan Al-Baihaqi). 


\section{Pustaka Acuan}

Âsyûr, Ibn, Maqâshid al-Syarî'ah al-Islâmiyyah, Mesir: Dâr al-Salâm, 2005.

Daradjat, Zakia, Ilmu Pendidikan Islam, Jakarta: Bumi Aksara,1996.

Hafidhuddin, Didin, Sifat Etos Kerja Muslim, artikel diakses 15 Oktober 2014 dari http://persis.or.id/site/modules. php?name $=$ News\&file=article $=84$,

Hasballah ,Ali, Ushûl al-Tasyrî̀ al-Islâmi, Bairut: Dâr al-Fikr al-Arabi, 1982.

Husayn Al-'Amiri,'Abdallah M.,Dekonstruksi Sumber Hukum Islam: Pemikiran Hukum Najm ad-Din Thufi, terj. Abdul Basir, Jakarta: Gaya Media Pratama.

Kamus Besar Bahasa Indonesia, Jakarta, PT Gramedia Pustaka Utama,2008 Prabu mangkunegara, AA Anwar, Evaluasi Kinerja SDM, Bandung : Refika Aditama, 2007

Siagian, Sondang P, Teori Motivasi dan Aplikasinya Jakarta: PT.Rineka Cipta, 1995

Sulistiyani, Ambar Teguh dan Rosidah, Manajemen Sumber Daya Manusia, Yogyakarta: Graha Ilmu, 2003.

Suma, Amin, FSH UIN Syarif Hidayatullah Jakarta; Potret, Keadaan dan Prospeknya, Jakarta, FSH Press, 2013.

Swastha, Basu, Azas-Azas Manajemen Modern, Yogyakarta: Liberty. 2000

Syâtibi, Abû Ishâq, al-Muwâfaqât fi Ushûl al-Syarî́ah, Beirut: Dar al-Kutub al'Ilmiyyah, t.th.

Yasmin, Ummu, Materi Tarbiyah: Panduan Kurikulum bagi Da’i dan Murabbi, Solo: Media Insani Press, 2005. 